\title{
14: 104330732-104306753
}

National Cancer Institute

\section{Source}

National Cancer Institute. 14: 104330732-104306753. NCI Thesaurus. Code C41678.

Physical location of AKT1_Gene 